\title{
Assessment of Heavy Metal Contaminants Using Pollution Indices in Ankobra River at Prestea Huni-Valley District, Ghana
}

\author{
Austin Asare1*, Benjamin D. Asamoah ${ }^{2}$, Peter 0. Sanful ${ }^{3}$ \\ ${ }^{1}$ Department of Environmental Management, University of Energy and Natural Resources, Sunyani, Ghana \\ ${ }^{2}$ Department of Chemical Sciences, University of Energy and Natural Resources, Sunyani, Ghana \\ ${ }^{3}$ Department of Fisheries and Water Resources, University of Energy and Natural Resources, Sunyani, Ghana \\ Email: *austin.asare@uenr.edu.gh
}

How to cite this paper: Asare, A., Asamoah, B. D., \& Sanful, P. O. (2019). Assessment of Heavy Metal Contaminants Using Pollution Indices in Ankobra River at Prestea Huni-Valley District, Ghana. Journal of Geoscience and Environment Protection, 7, 25-35.

https://doi.org/10.4236/gep.2019.79003

Received: August 6, 2019

Accepted: September 16, 2019

Published: September 19, 2019

Copyright $\odot 2019$ by author(s) and Scientific Research Publishing Inc. This work is licensed under the Creative Commons Attribution International License (CC BY 4.0).

http://creativecommons.org/licenses/by/4.0/

cC) (7) Open Access

\begin{abstract}
The reliance of communities on River Ankobra as the source of drinking water makes the assessment of its quality very imperative to human health and environmental management. The objective of this work was to investigate the concentration of heavy metal in the Ankobra River sediments at the Prestea Huni-Valley District using pollution indices. Sediments were collected randomly from the bottom of the Ankobra River at four different communities namely: Awodua, Heman, Ankobra and Tarkwa Breman. The presence of a set of heavy metals $\mathrm{Fe}, \mathrm{Mn}, \mathrm{Cd}, \mathrm{Pb}, \mathrm{Zn}, \mathrm{Cu}$, and $\mathrm{Hg}$ in the sediments was determined using Atomic Absorption Spectroscopy (AAS). The results showed that the concentration of $\mathrm{Fe}, \mathrm{As}$, and $\mathrm{Hg}$ did not differ significantly $(p>0.05)$ amongst the four communities but significant variation in the levels of $\mathrm{Cu}$, $\mathrm{Mn}, \mathrm{Cd}, \mathrm{Pb}$, and $\mathrm{Zn}$ was found $(p<0.05)$ amongst the sampling areas. The geo-accumulation index revealed that the communities were not polluted with $\mathrm{Cu}, \mathrm{Mn}, \mathrm{Fe}, \mathrm{Pb}$ and $\mathrm{Zn}$. However, all communities except Tarkwa Breman were found to have exceptionally high levels of $\mathrm{Cd}$. The contamination factor results were consistent with the I-geo results. The pollution load index (PLI) showed that the four communities were not polluted with heavy metals. Strong statistical positive relationship were found between $\mathrm{Mn}$ and $\mathrm{Cu} ; \mathrm{Cd}$ and $\mathrm{Cu} ; \mathrm{Pb}$ and $\mathrm{Mn} ; \mathrm{Hg}$ and $\mathrm{Mn} ; \mathrm{Zn}$ and $\mathrm{Cu} ; \mathrm{Zn}$ and $\mathrm{Mn} ; \mathrm{Zn}$ and $\mathrm{Pb} ; \mathrm{Zn}$ and $\mathrm{Hg}$ whilst $\mathrm{As}$ and $\mathrm{Fe}$ showed strong negative correlation.
\end{abstract}

\section{Keywords}

Heavy Metal, Ankobra River, Pollution Index, Sediment 


\section{Introduction}

The assessment of heavy metal pollution in river systems and other surface water bodies has received considerable attention in recent years (Smolders et al., 2002; Bacon \& Davidson, 2008). The effective management of river catchments against anthropogenic driven heavy metal pollution is affected by a range of challenges stemming from differing national priorities, governance of land use activities, resource use, and differences in institutional capacity, data gathering and data sharing (Benger \& Simon, 2009). Heavy metals, regarded as serious pollutants due to their detrimental effects on aquatic ecosystems, and environmental persistence and toxicity can lead to bioaccumulation and biomagnification in living organisms and food chains respectively (Armitage et al., 2007). Metals enter rivers via a variety of sources, such as natural chemical weathering of rocks, atmospheric deposition, agricultural activities, mining and improper disposal of untreated waste (Olayinka, 2004). Ankobra River basin is one of the main mining areas in Ghana. Notwithstanding, the gains from mining are at the risk of great environmental cost as the exploitation of gold and other precious minerals puts stress on water, soil, vegetation and poses human health hazards (Amonoo-Neizer \& Amekor, 1993). The major minerals mined in the area are gold, manganese, bauxite and diamond. The excessive and uncontrolled mining activities in the Ankobra basin have led to severe environmental pollution (Fatoki et al., 2001). If pollution is allowed to grow unchecked in the Ankobra River, the subsequent result may be impairment of aquatic ecosystems and detrimental effects on human health (Fatoki et al., 2001).

In Ghana, several studies have been conducted to ascertain the levels of heavy metals in aquatic ecosystems largely affected by mining activities (Donkor et al., 2006; Hayford, Amin, Osae, \& Kutu, 2008). Specifically, studies carried out in the Ankobra River basins have highlighted the presence of some heavy metals such as mercury, lead, and arsenic (Bannerman et al., 2003). In the last decade especially, there has been significant increase in mining activities following the legalization of small-scale mining, together with illegal artisanal mining activities. It is therefore expected that the heavy metal levels could potentially increase above internationally accepted limits within the catchment of the Ankobra River (Donkor et al., 2006). A recent report on Groundwater Inventory and Hydro-geological Assessment on the Ankobra River Basin submitted to the Water Resources Commission by the Water Research Institute of Ghana indicated alarming levels of metals in the river (Myjoyonline, 2015).

Though results from previous investigations of the heavy metal pollutants in the Ankobra River have provided important insights, the use of indices such as Pollution Load Index (PLI), Contamination Factor (CF), Geo-accumulation Index (I-geo) are not been explored. The objective of this work therefore was to assess the concentration of heavy metals in the Ankobra river sediments at four sites corresponding to four communities in the Prestea Huni-Valley District of Ghana using pollution indices 


\section{Materials and Method}

\subsection{Study Area}

This study was carried out at Awodua, Heman, Ankobra and Tarkwa Breman communities, in the Huni Valley district of the Western Region of Ghana (Figure 1). Located at latitude $4^{\circ} 53^{\prime} 55^{\prime \prime} \mathrm{N}$ and longitude $2^{\circ} 16^{\prime} 17^{\prime \prime} \mathrm{W}$, the Ankobra River is approximately $222 \mathrm{~km}$ long and has a catchment area of $8366 \mathrm{~km}^{2}$ with an annual rainfall between $1520-2200 \mathrm{~mm}$ (WRC, 2012). The river takes its source in north from Bibiani Hills at $368 \mathrm{~m}$ above sea level in the Sefwi Bekwai District and discharges into the Gulf of Guinea in the south. The major rainy season occurs around May-August and a minor one in September-October with air temperatures ranging between $21^{\circ} \mathrm{C}$ and $32^{\circ} \mathrm{C}$. Awodua, Heman and Ankobra communities were within the mining operation zone of the district whereas Tarkwa Breman was outside the zone of impact of the mining operations and was therefore used as the control site for this study.

\subsection{Sample Collection}

Sediment samples were collected in June, 2016, from each of the four communities along the Ankobra River. At each site, a soil auger was used to take four replicates of sediments at $15 \mathrm{~cm}$ depth. This depth according to Santos-Santos et al. (2006) is the depth at which heavy metals in sediments accumulate. The sediment

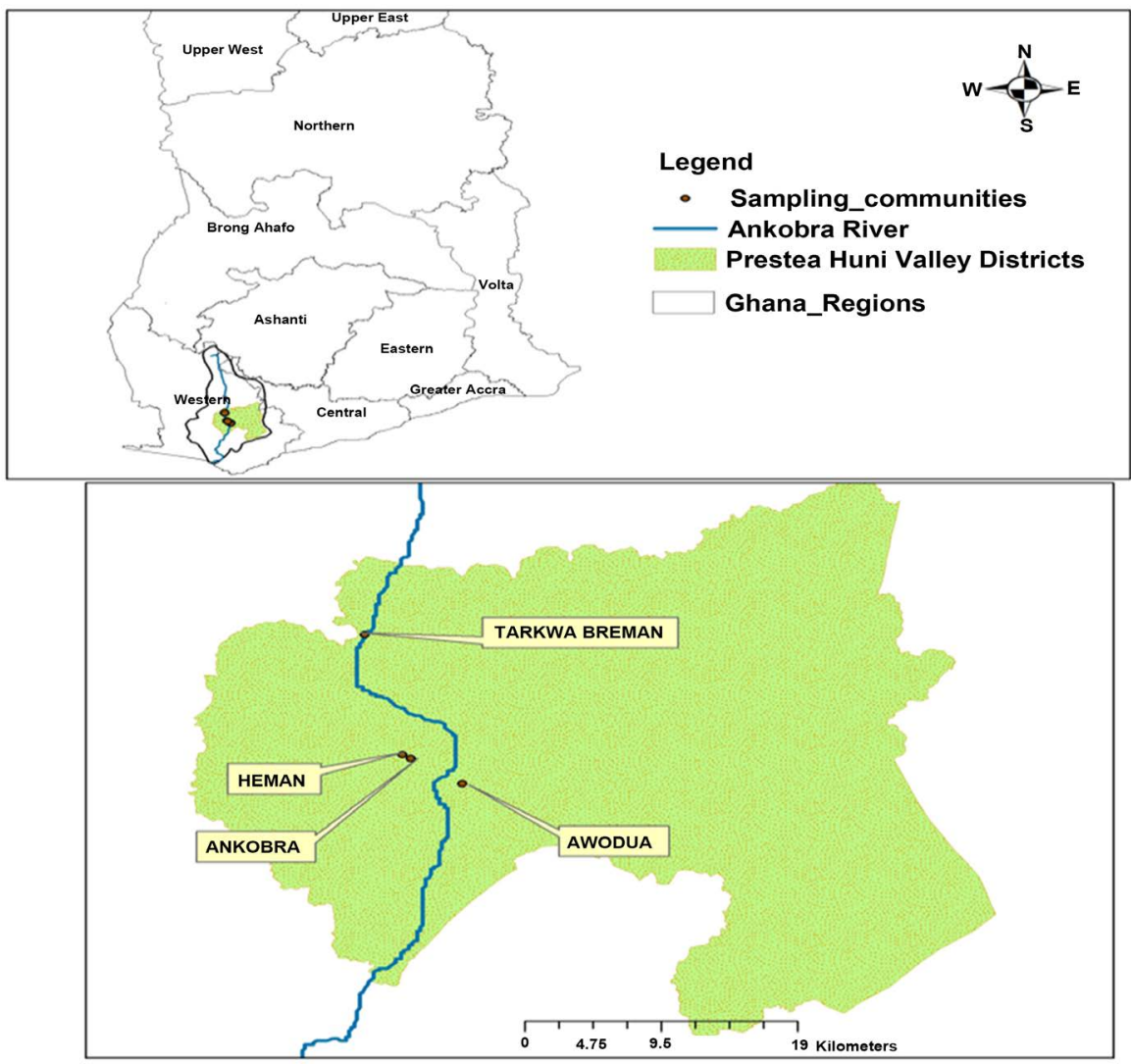

Figure 1. Location of the study area and sampling sites in relation to the Ankobra River catchment. 
samples were stored in sterilized plastic bags, labeled, and kept frozen for analysis in the laboratory according to Sakan et al. (2007). In the laboratory, sediment were dried at room temperature, grinded and homogenized in a mortar to a fine powder. The samples were acid digested using aqua regia $\left(\mathrm{HCl}: \mathrm{HNO}_{3} ; 3.1\right)$. Sediment $\mathrm{pH}$ was measured with a $\mathrm{pH}$ meter. Heavy metals namely: $\mathrm{As}, \mathrm{Pb}, \mathrm{Mn}$, $\mathrm{Zn}, \mathrm{Fe}, \mathrm{Hg}, \mathrm{Cu}$, and $\mathrm{Cd}$ were analysed by Atomic Absorption Spectrophotometer (AAS).

The Pollution Load Index (PLI) and Geoaccumulation Index (Igeo) were computed for the sediment data using MINITAB software. PLI is an empirical index which provides a simple, comparative means for assessing the level of trace elements pollution (Tomlinson et al., 1980). The PLI was therefore used to assess pollution severity and its variation among the study sites. Additionally, the sediment pollution status of the studied sites was quantified using the Contamination Factor (CF) approach according to the method used by Nyarko et al. (2004). The equation used is given by;

$$
C F=\frac{C s}{B n}
$$

where $C F$ is the ratio obtained by dividing the concentration of each element in the sediment $(C S)$ by the baseline or background value $(B n)$ (concentration in unpolluted soil).

$P L I$ was therefore used to find out the mutual pollution effect of the heavy metals on each of the sampling sites. The $P L I$ values were calculated as the nth root of the product of the $n t h C F$ (Boamponsem et al., 2010).

$$
P L I=\sqrt[n]{C F 1, C F 2, C F 3, \cdots, C F n t h}
$$

where, $n$ is the number of metals (six in the present study). Geo-accumulation index was used to quantify the degree of anthropogenic contamination in sediments. Geo-accumulation indices for the heavy metals in each sampling site were calculated using the equation:

$$
I G E O=\frac{\log _{2} C n}{1.5 B n}
$$

where $C n$ is the concentration of the element in the sediment and $B n$ is the geochemical background concentration of the metal $(n)$ in the world average shale (Bhuiyan et al., 2010). The constant 1.5 accounts for natural fluctuations in the content of a given substance in the environment as well as very small anthropogenic influences.

The geoaccumulation index consists of seven grades or classes ranging from unpolluted to extremely polluted (Muller, 1981).

The mean heavy metal concentrations were compared using One-way analysis of variance in IBM SPSS version 21 software environment.

The interrelationships among heavy metal concentrations in unpolluted and polluted sediment samples were analysed using Spearman's Ranks non-parametric correlation methods of the IBM SPSS software. 


\section{Results and Discussion}

For comparative purposes, the results of the analysis of heavy metals have been compared with Clarke values which are the mean concentrations of the chemical elements in the upper continental crust (McLennan, 2001). Soil pH in the sediments of Ankobra River at the different sampling locations has also been compared to WHO values. The data obtained from the study have been presented in Tables 1-4.

\section{1. pH Levels}

The soil $\mathrm{pH}$ in the sediments of the Ankobra River (Table 1) reveals the degree of acidity or alkalinity of the sediments. The mean $\mathrm{pH}$ level of sediments across the different sampling locations did not vary significantly $(p>0.05)$. $\mathrm{pH}$ is one of the major parameters that explains the mobility of heavy metals in soils and sediments (Gäbler, 1997). Though the $\mathrm{pH}$ values recorded in the study were less than 7 (acidic), they were within acceptable range according to WHO standards and are not likely to influence the solubility of heavy metals in the sediments and their transformation into other chemical species.

The relatively high levels of $\mathrm{Cd}, \mathrm{Hg}$, and As at Awodua, Heman, and Ankobra, may probably be due to high solubility of fulvic acids (FAs) and humic acids (HAs) at near-neutral pH (Cappuyns \& Swennen, 2008). FAs and HAs which are naturally found in the humus of soils and sediments, and are usually coordinated to relatively lighter metal ions such as $\mathrm{Ca} 2+$ and Mn2+ (Morse \& Luther, 1999). These light metal ions can undergo cation exchange with heavy meatal ions such as $\mathrm{Cd} 2+$ and $\mathrm{Hg} 2+$ which eventually binds to the FAs and HAs to form complexes in the sediments that lead to heavy metal accumulation.

\subsection{Heavy Metal Concentrations}

The variation of the eight heavy metals, $\mathrm{Cu}, \mathrm{Mn}, \mathrm{Cd}, \mathrm{Fe}, \mathrm{Pb}, \mathrm{As}, \mathrm{Hg}$, and $\mathrm{Zn}$ concentrations at the different locations are listed in Table 1. The concentrations of $\mathrm{Cu}, \mathrm{Mn}, \mathrm{Cd}, \mathrm{Zn}$, and $\mathrm{Pb}$ differed significantly across the four sampling locations $(p<0.001$, except $\mathrm{Pb}$ with $p<0.05)$ whereas the concentrations of $\mathrm{Fe}$, As, and $\mathrm{Hg}$ showed no significant difference in the study areas $(p>0.05)$. From the Fisher's multiple comparison test, the sediments at Awodua, Heman and Ankobra did not vary significantly than the concentration recorded at Tarkwa Breman with respect to $\mathrm{Cu}, \mathrm{Cd}, \mathrm{Mn}$, and $\mathrm{Zn}$. This means that both mined and unmined sites had similar levels of heavy metals indicating that mining activities were not contributing to heavy metal pollution in the mining areas. Based on Clark's geochemical background values $(25,600,35000,17$ and 71$) \mathrm{mg} / \mathrm{kg}$ (McLennan, 2001), variation mean concentration of $\mathrm{Cu}, \mathrm{Mn}, \mathrm{Fe}, \mathrm{Pb}$, and $\mathrm{Zn}$ in the sediments across sampling locations indicates absence of heavy metals in the sediments. However, comparison of $\mathrm{Cd}, \mathrm{Hg}$, and As, with Clark geochemical background value $(0.10,0.21$, and 1.50$) \mathrm{mg} / \mathrm{kg}$ respectively, showed high levels of heavy metals at Awodua, Heman, and Ankobra only. The rise in $\mathrm{Cd}, \mathrm{Hg}$, and 
Table 1. Mean, WHO and Clark values of heavy metal contents in the Ankobra River sediments.

\begin{tabular}{|c|c|c|c|c|c|c|c|c|c|}
\hline SC & $\mathrm{pH}$ & $\mathrm{Cu}$ & $\mathrm{Mn}$ & $\mathrm{Cd}$ & $\mathrm{Fe}$ & $\mathrm{Pb}$ & As & $\mathrm{Hg}$ & $\mathrm{Zn}$ \\
\hline \multirow[t]{2}{*}{ AW } & $6.6 \pm 0.6 \mathrm{a}$ & $6.6 \pm 1.9 \mathrm{a}$ & $54.2 \pm 0.2 \mathrm{a}$ & $1.1 \pm 0.09 \mathrm{a}$ & $8.6 \pm 1.9 a$ & $4.8 \pm 1.0 \mathrm{a}$ & $2.0 \pm 3.0 \mathrm{a}$ & $0.5 \pm 0.6 \mathrm{a}$ & $1.1 \pm 0.2 \mathrm{a}$ \\
\hline & $(5.8-7.2)$ & $(5-9.4)$ & $(54-54.5)$ & $(1-1.2)$ & $(6.7-10.9)$ & $(4-6.2)$ & $(0.1-6.4)$ & $(0.03-1.4)$ & $(1-1.37)$ \\
\hline \multirow[t]{2}{*}{$\mathrm{H}$} & $6.8 \pm 0.6 \mathrm{a}$ & $5.9 \pm 0.6 \mathrm{a}$ & $54.4 \pm 0.3 a$ & $1.01 \pm 0.01 \mathrm{a}$ & $6.6 \pm 1.7 \mathrm{a}$ & $5.7 \pm 2.8 \mathrm{a}$ & $5.5 \pm 4.7 \mathrm{a}$ & $0.3 \pm 0.2 \mathrm{a}$ & $1.1 \pm 0.1 \mathrm{a}$ \\
\hline & $(5.9-7.3)$ & $(5-6.4)$ & $(54.1-54.6)$ & $(1-1.03)$ & $(4.9-8.2)$ & $(4-9.9)$ & $(1.6-12)$ & $(0.06-0.4)$ & $(0.95-1.2)$ \\
\hline \multirow[t]{2}{*}{ AN } & $6.6 \pm 0.5 a$ & $5.3 \pm 0.5 a$ & $54.2 \pm 0.13 a$ & $1.05 \pm 0.1 \mathrm{a}$ & $14.2 \pm 15.8 \mathrm{a}$ & $4.1 \pm 0.1 \mathrm{ab}$ & $1.5 \pm 1.4 \mathrm{a}$ & $0.22 \pm 0.2 \mathrm{a}$ & $1.13 \pm 0.3 \mathrm{a}$ \\
\hline & $(5.95-7)$ & $(5-6.03)$ & $(54.1-54.3)$ & $(1.01-1.13)$ & $(4.8-37.8)$ & $(4-4.13)$ & $(0.11-3)$ & $(0.03-0.5)$ & $(0.95-1.52)$ \\
\hline \multirow[t]{2}{*}{$\mathrm{TB}$} & $6.5 \pm 1.1 \mathrm{a}$ & $0.6 \pm 0.9 b$ & $13.4 \pm 0.4 \mathrm{~b}$ & $0.02 \pm 0.03 b$ & $19.6 \pm 22.2 \mathrm{a}$ & $1.8 \pm 0.3 b$ & $0.8 \pm 0.3 a$ & $0.05 \pm 0 \mathrm{a}$ & $0.4 \pm 0.2 \mathrm{~b}$ \\
\hline & $(4.8-7.3)$ & $(0.02-2)$ & $(13.1-13.9)$ & $(0.002-0.06)$ & $(5.2-52.6)$ & $(1.5-2.3)$ & $(0.3-1.1)$ & $(0.052-0.1)$ & $(0.1-0.6)$ \\
\hline$p$-value & 0.962 & 0.000 & 0.000 & 0.000 & 0.550 & 0.021 & 0.153 & 0.309 & 0.000 \\
\hline F-ratio & 0.09 & 22.58 & 24842.43 & 346.22 & 0.74 & 4.77 & 2.11 & 1.33 & 15.09 \\
\hline $\mathrm{df}$ & 3 & 3 & 3 & 3 & 3 & 3 & 3 & 3 & 3 \\
\hline $\begin{array}{l}{ }^{\mathrm{a}} \text { Clark } \\
\text { Values }\end{array}$ & - & 25 & 600 & 0.10 & 35000 & 17 & 1.5 & 0.21 & 71 \\
\hline WHO & $6.5-8.5$ & 1 & 0.40 & 0.003 & 0.30 & 0.01 & 0.01 & 0.01 & 3 \\
\hline
\end{tabular}

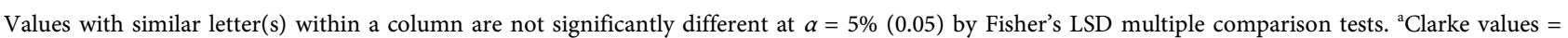
mean concentrations of the chemical elements in the upper continental crust (UCC) given by McLennan (2001); Geochemical data are expressed in mg/kg; The values in the parenthesis represent range, $\mathrm{NB}: \mathrm{AW}=$ Awodua; $\mathrm{H}=$ Heman; $\mathrm{AN}=$ Ankobra; $\mathrm{TB}=$ Tarkwa Breman; $\mathrm{SC}=$ Sampling Communities.

As levels at Awodua, Heman and Ankobra could be probably due to prevalence of illegal small scale gold mining popularly referred to as "galamsey" in the vicinity of these areas (Mwashote, 2003).

\subsection{Geo-Accumulation Index (I-geo)}

The geo-accumulation index is a quantitative measure of the degree of pollution in aquatic sediments (Ji et al., 2008). Based on the Muller's classification, this index includes 7 classes: Igeo $\leq 0$ (class 0 ): practically unpolluted; $0<$ Igeo $>1$ (class 1): unpolluted to moderately polluted; $1<$ Igeo $>2$ (class 2 ): Moderately polluted; $2<$ Igeo $>3$ (class 3): Moderately to strongly polluted; $3<$ Igeo $>4$ (class 4): Strongly polluted; $4<$ Igeo $>5$ (class 5): Strongly to extremely polluted; 5 < Igeo (class 6): Extremely polluted (Varol, 2011). Table 2 presents the geo-accumulation index for the quantification of heavy metal accumulation in the study area. The I-geo for $\mathrm{Cu}, \mathrm{Mn}, \mathrm{Fe}, \mathrm{Pb}$ and $\mathrm{Zn}$ were in class 0 (unpolluted) at Awodua, Heman, Ankobra, and Tarkwa Breman suggesting that the Ankobra River sediments were within the natural background values of these metals (Syed et al., 2012). However the I-geo for Cd at Awodua, Heman, and Ankobra fell within the moderately to strongly polluted range, indicating anthropogenic influences. The pollution could be due to human activities such as mining and agriculture along the Ankobra River as noted by Mwashote (2003). Notwithstanding, the I-geo for Cadmium Cd at Tarkwa Breman fell within unpolluted range indicating the absence of $\mathrm{Cd}$ in the sediments. The geo-accumulation index (I-geo) for arsenic (As), at Awodua, Tarkwa Breman, and Ankobra, were 
Table 2. Geo-accumulation index for heavy metals in sediment of Ankobra River at the different sampling locations. Geochemical background values were taken from Clarke Upper Continental Crust (UCC) given by McLennan (2001) expressed in mg/kg.

\begin{tabular}{ccccccccc}
\hline SC & I-geo $(\mathrm{Cu})$ & I-geo $(\mathrm{Mn})$ & I-geo $(\mathrm{Cd})$ & I-geo $(\mathrm{Fe})$ & I-geo $(\mathrm{Pb})$ & I-geo $(\mathrm{As})$ & I-geo $(\mathrm{Hg})$ & I-geo $(\mathrm{Zn})$ \\
\hline AW & -2.506 & -4.054 & 2.874 & -12.576 & -2.409 & -0.170 & 0.737 & -6.597 \\
H & -2.668 & -4.048 & 2.751 & -12.958 & -2.161 & 1.290 & 0.000 & -6.597 \\
AN & -2.823 & -4.054 & 2.807 & -11.852 & -2.637 & -0.585 & -0.447 & -6.558 \\
TB & -5.966 & -6.070 & -2.907 & -11.387 & -3.824 & -1.492 & -2.585 & -8.057 \\
\hline
\end{tabular}

NB: $\mathrm{AW}=$ Awodua; $\mathrm{H}=$ Heman; $\mathrm{AN}=$ Ankobra; $\mathrm{TB}=$ Tarkwa Breman.

also within the unpolluted region except the I-geo for As at Heman which fell in class 2 (Moderately polluted). The I-geo for mercury (Hg) at Heman, Ankobra, and Tarkwa Breman fell in class 0 whilst the I-geo for $\mathrm{Hg}$ at Awodua fell in class 1 (unpolluted to moderately polluted). The low level of heavy metals in the sediments at Tarkwa Breman may be due to the absence of mining activities in the area. Tarkwa Breman was used as the control site and absence of the heavy metals indicates that mining is a major factor driving heavy metal pollution in sediments in the other study communities.

\subsection{Pollution Load Index (PLI) and Contamination Factor (CF)}

Table 3 presents the contamination factor (CF) and Pollution load index (PLI) for the quantification of heavy metal accumulation in the four communities. Generally, the pollution load index of heavy metals for the four different sampling locations was below $1(\mathrm{PLI}<1)$ indicating that the sediments of the sampling locations were not polluted with heavy metals (Tomlinson et al., 1980; Syed et al., 2012). Notwithstanding, the contamination factor results showed that $\mathrm{Cu}, \mathrm{Mn}, \mathrm{Fe}, \mathrm{Pb}$, and $\mathrm{Zn}$ fell within the low contamination category $(\mathrm{CF}<1)$. Although CF for Cd, As, and Hg was less than 1 at Tarkwa Breman (low contamination), that of Awodua, Heman, and Ankobra recorded a variable contamination levels. For $\mathrm{Cd}$, there was a very high contamination $(6 \leq \mathrm{CF})$ at the three areas. The high CF in these areas could be due to the prevalence of mining activities as noted by Dupler et al. (2001) who reported that human activities such as mining and agriculture are the major cause of metal pollution. There was absence of heavy metals Tarkwa Breman community due to the absence of mining activities. For As, at Awodua and Ankobra, $1 \leq \mathrm{CF}<3$ (moderate contamination), whereas at Heman, $3 \leq \mathrm{CF}<6$ (considerable contamination). In terms of the $\mathrm{CF}$ for $\mathrm{Hg}$; all three sample locations were moderately contaminated $(1 \leq \mathrm{CF}<3)$.

\subsection{Correlation Analysis among Parameters}

The inter-elemental association was evaluated by Spearman's Rank correlation coefficients matrix (1-tailed) to deduce possible common sources of the origin of the heavy metals. Strong linear correlations between parameters indicate similar origins of these elements and the main factors controlling their availability and variability. Table 4 shows that elemental pairs $\mathrm{Mn} / \mathrm{Cu}(\mathrm{r}=0.5, p<0.05) ; \mathrm{Cd} / \mathrm{Cu}$ 
Table 3. Contamination Factor $(C F)$ and Pollution Load Index ( $P L I)$ for studied heavy metals in sediment of Ankobra River at the four different sampling locations. Geochemical background values were taken from Clarke Upper Continental Crust (UCC) given by McLennan (2001) expressed in $\mathrm{mg} / \mathrm{kg}$.

\begin{tabular}{cccccccccc}
\hline $\mathrm{SC}$ & $\mathrm{CF}(\mathrm{Cu})$ & $\mathrm{CF}(\mathrm{Mn})$ & $\mathrm{CF}(\mathrm{Cd})$ & $\mathrm{CF}(\mathrm{Fe})$ & $\mathrm{CF}(\mathrm{Pb})$ & $\mathrm{CF}(\mathrm{As})$ & $\mathrm{CF}(\mathrm{Hg})$ & $\mathrm{CF}(\mathrm{Zn})$ & PLI \\
\hline AW & 0.2640 & 0.0903 & 11.0000 & 0.0002 & 0.2824 & 1.3333 & 2.5000 & 0.0155 & 0.1765 \\
$\mathrm{HIM}$ & 0.2360 & 0.0907 & 10.1000 & 0.0002 & 0.3353 & 3.6667 & 1.5000 & 0.0155 & 0.1812 \\
ANK & 0.2120 & 0.0903 & 10.5000 & 0.0004 & 0.2412 & 1.0000 & 1.1000 & 0.0159 & 0.1556 \\
KAN & 0.0240 & 0.0223 & 0.2000 & 0.0006 & 0.1059 & 0.5333 & 0.2500 & 0.0056 & 0.0384 \\
\hline
\end{tabular}

$\mathrm{CF}<1$ (low contamination); $1 \leq \mathrm{CF}<3$ (Moderate); $3 \leq \mathrm{CF}<6$ (Considerable contamination); $6 \leq \mathrm{CF}$ (Very high contamination) (Source: Syed et al., 2012) where a value of PLI $<1$ denote perfection; PLI $=1$ present that only baseline levels of pollutants are present and PLI $>1$ would indicate deterioration of site quality NB: $\mathrm{AW}=$ Awodua; $\mathrm{H}=$ Heman; $\mathrm{AN}=$ Ankobra; $\mathrm{TB}=$ Tarkwa Breman.

Table 4. Spearman's rank correlation coefficient matrix for heavy metals in the sediments of Ankobra River.

\begin{tabular}{|c|c|c|c|c|c|c|c|c|c|}
\hline & $\mathrm{pH}$ & $\mathrm{Cu}$ & $\mathrm{Mn}$ & $\mathrm{Cd}$ & $\mathrm{Fe}$ & $\mathrm{Pb}$ & As & $\mathrm{Hg}$ & $\mathrm{Zn}$ \\
\hline $\mathrm{pH}$ & 1 & & & & & & & & \\
\hline $\mathrm{Cu}$ & -0.035 & 1 & & & & & & & \\
\hline $\mathrm{Mn}$ & 0.143 & $0.500^{*}$ & 1 & & & & & & \\
\hline $\mathrm{Cd}$ & 0.092 & $0.639^{* *}$ & 0.418 & 1 & & & & & \\
\hline $\mathrm{Fe}$ & 0.235 & -0.365 & -0.118 & -0.112 & 1 & & & & \\
\hline $\mathrm{Pb}$ & -0.14 & 0.493 & $0.574^{*}$ & $0.553^{*}$ & -0.031 & 1 & & & \\
\hline As & -0.117 & 0.292 & 0.206 & 0.141 & $-0.591^{*}$ & 0.34 & 1 & & \\
\hline $\mathrm{Hg}$ & -0.117 & 0.32 & $0.649^{* *}$ & -0.03 & 0.009 & 0.42 & 0.092 & 1 & \\
\hline $\mathrm{Zn}$ & -0.25 & $0.733^{* *}$ & $0.729 * *$ & 0.457 & -0.053 & $0.555^{*}$ & 0.212 & $0.707^{* *}$ & 1 \\
\hline
\end{tabular}

${ }^{\star}$ Correlation is significant at the 0.05 level (2-tailed); ${ }^{* *}$ Correlation is significant at the 0.01 level (2-tailed).

$(\mathrm{r}=0.639, p<0.01) ; \mathrm{Pb} / \mathrm{Mn}(\mathrm{r}=0.574, p<0.05) ; \mathrm{Hg} / \mathrm{Mn}(\mathrm{r}=0.649, p<0.01)$; $\mathrm{Zn} / \mathrm{Cu}(\mathrm{r}=0.733, p<0.01) ; \mathrm{Zn} / \mathrm{Mn}(\mathrm{r}=0.729, p<0.01) ; \mathrm{Zn} / \mathrm{Pb}(\mathrm{r}=0.55, p<$ $0.05)$ and $\mathrm{Zn} / \mathrm{Hg}(\mathrm{r}=0.707, p<0.01)$; are significantly and positively correlated with each other. However, the elemental pairs As/Fe $(\mathrm{r}=-0.591, p<0.05)$ are significantly and negatively correlated with each other. The rest of the elemental pairs showed no significant correlation with each other. The high correlations between soil heavy metals may reflect the fact that these heavy metals have similar pollution sources or metal origin.

\section{Conclusion}

This study assessed heavy metal contamination of sediments in Ankobra River at four communities in the Prestea Huni-Valley district of Ghana using pollution indices. One of the communities, Tarkwa Breman was devoid of mining activity and therefore was used as control site to evaluate the presence of heavy metals caused by mining activities relative to natural background levels. The geoaccumulation index revealed that the sediments at Awodua, Heman and Ankobra had moderately high levels of $\mathrm{Cd}$. However, the pollution load index showed no 
contamination of heavy metals. According to this study, natural and anthropogenic activities may have played a role in the presence of heavy metals in the sediments of the Ankobra River.

\section{Acknowledgements}

We wish to express our heartfelt gratitude to the chiefs and people of Awodua, Tarkwa Breman, Ankobra, and Heman for their hospitality during the sampling.

\section{Conflicts of Interest}

The authors declare no conflicts of interest regarding the publication of this paper.

\section{References}

Amonoo-Neizer, E. H., \& Amekor, E. M. K. (1993). Determination of Total Arsenic in Environmental Samples from Kumasi and Obuasi, Ghana. Environmental Health Perspectives, 101, 44-49. https://doi.org/10.1289/ehp.9310146

Armitage, P. D., Bowes, M. J., \& Vincent, H. M. (2007). Long-Term Changes in Macroinvertebrate Communities of a Heavy Metal Polluted Stream: The River Nent (Cumbria, UK) after 28 Years. River Research and Applications, 23, 997-1015. https://doi.org/10.1002/rra.1022

Bacon, J. R., \& Davidson, C. M. (2008). Is There a Future for Sequential Chemical Extraction? Analyst, 133, 25-46. https://doi.org/10.1039/B711896A

Bannerman, W., Potin-Gautier, M., Amouroux, D., Tellier, S., Rambaud, A., Babut, M., \& Beinhoff, C. (2003). Mercury and Arsenic in the Gold Mining Regions of the Ankobra River Basin in Ghana. Journal de Physique IV, 107, 107-110.

Benger, A., \& Simon, N. (2009). Remote Sensing of the Ecology and Functioning of the Mekong River Basin with Special Reference to the Tonle Sap. Adelaide, Australia: Flinders University.

Bhuiyan, M. A. H., Parvez, L., Islam, M. A., Dampare, S., B., \& Suzuki, S. (2010). Heavy Metal Pollution of Coal Mine-Affected Agricultural Soils in the Northern Part of Bangladesh. Journal of Hazardous Materials, 179, 1065-1077. https://doi.org/10.1016/j.jhazmat.2009.08.085

Boamponsem, L. K., Adam, J. I., Dampare, S. B, OwusuAnsah, E., \& Addae, G. (2010). Heavy Metal Levels in Streams at Tarkwa Gold Mining Area of Ghana. Journal of Chemical and Pharmaceutical Research, 2, 504-527.

Cappuyns, V., \& Swennen, R. (2008). The Application of pHstat Leaching Tests to Assess the $\mathrm{pH}$-Dependent Release of Trace Metals from Soils, Sediments and Waste Materials. Journal of Hazardous Materials, 158, 185-195. https://doi.org/10.1016/j.jhazmat.2008.01.058

Donkor, A. K., Nartey, V. K., Bonzongo, J. C., \& Adotey, D. K. (2006). Artisanal Mining of Gold with Mercury in Ghana. West African Journal of Applied Ecology, 9, 1-8. https://doi.org/10.4314/wajae.v9i1.45666

Dupler, D. et al. (2001). Heavy Metal Poisoning. Gale Encyclopedia of Alternative Medicine. Farmington Hills, MI: Gale Group.

Fatoki, O. S., Muyima, N. Y. O., \& Lujiza, N. (2001). Situation Analysis of Water Quality in the Umtata River Catchment. Water SA, 27, 467-474. 
https://doi.org/10.4314/wsa.v27i4.4959

Gäbler, H. E. (1997). Mobility of Heavy Metals as a Function of pH of Samples from an Overbank Sediment Profile Contaminated by Mining Activities. Journal of Geochemical Exploration, 58, 185-194. https://doi.org/10.1016/S0375-6742(96)00061-1

Hayford, E. K., Amin, A., Osae, E. K., \& Kutu, J. (2008). Impact of Gold Mining on Soil and some Staple Foods Collected from Selected Mining Communities in and around Tarkwa-Prestea Area. West African Journal of Applied Ecology, 14, 1-12.

https://doi.org/10.4314/wajae.v14i1.44708

Ji, Y., Feng, Y., Wu, J., Zhu, T., Bai, Z., \& Duan, C. (2008). Using Geoaccumulation Index to Study Source Profiles of Soil Dust in China. Journal of Environmental Sciences, 20, 571-578. https://doi.org/10.1016/S1001-0742(08)62096-3

McLennan, S. M. (2001). Relationships between the Trace Element Composition of Sedimentary Rocks and Upper Continental Crust. Geochemistry, Geophysics, Geosystems, 2. https://doi.org/10.1029/2000GC000109

Morse, J. W., \& Luther, G. W. (1999). Chemical Influences on Trace Metal-Sulfide Interactions in Anoxic Sediments. Geochimica et Cosmochimica Acta, 63, 3373-3378. https://doi.org/10.1016/S0016-7037(99)00258-6

Muller, G. (1981). Die Schwermetallbelastung der sediment des Neckars und seiner Nebenflusse: EineBest and saufnahme. Chemiker Zeitung, 105, 156-164.

Mwashote, B. M. (2003). Levels of Cadmium and Lead in Water, Sediments and Selected Fish Species in Mombasa, Kenya. Western Indian Ocean Journal of Marine Science, 2, 25-34. https://doi.org/10.4314/wiojms.v2i1.28426

Myjoyonline (2015). ANKOBRA RIVER: A Haven for Fish Turned into Gold-Washing Tailings.

http://www.myjoyonline.com/news/2015/October-27th/ankobra-river-a-haven-for-fish -turned-into-gold-washing-tailings.php

Nyarko, B. J. B., Serfor-Armah, Y., Akaho, E. H. K., Adomako, D., \& Osae, S. (2004). Determination of Heavy Metal Pollution Levels in Lichens at Obuasi Gold Mining Area in Ghana. Journal of Applied Science and Technology, 9, 28-33. https://doi.org/10.4314/jast.v9i1.17439

Olayinka, K. O. (2004). Studies on Industrial Pollution in Nigeria: The Effect of Textile Effluents on the Quality of Groundwater in Some Parts of Lagos. Nigerian Journal of Health and Biomedical Sciences, 3, 27-30. https://doi.org/10.4314/njhbs.v3i1.11507

Sakan, S., Grzetic, I., \& Dordevic, D. (2007). Distribution and Fractionation of Heavy Metals in the Tisa (Tisza) River Sediments. Environmental Science and Pollution Research International, 14, 229-236. https://doi.org/10.1065/espr2006.05.304

Santos-Santos, E., Yarto-Ramírez, M., Gavilán-García, I., Castro-Díaz, J., Gavilán-García, A., Rosiles, R., Suárez, S., \& López-Villegas, T. (2006). Analysis of Arsenic, Lead and Mercury in Farming Areas with Mining Contaminated Soils at Zacatecas, Mexico. Journal of the Mexican Chemical Society, 50, 57-63.

Smolders, A. J. P., Guerrero Hiza, M. A., van der Velde, G., \& Roelofs, G. M. (2002). Dynamics of Discharge, Sediment Transport, Heavy Metal Uupollution and Sábalo (Prochilodus linetaus) Catches in the Lower Pilcomayo River. River Research and Applications, 18, 415-427.

Syed, H. R., Dilara, K., Tanveer, M. A., Mohammad, S. I., Mohammad, A. A., \& Ahedul-Akbor, M. (2012). Assessment of Heavy Metal Contamination of Agricultural Soil around Dhaka Export Processing Zone (DEPZ), Bangladesh: Implication of Seasonal Variation and Indices. Applied Sciences, 2, 584-601. 
https://doi.org/10.3390/app2030584

https://www.mdpi.com/journal/applsci

Tomlinson, D. C., Wilson, D. J., Harris, C. R., \& Jeffrey, D. W. (1980). Problem in Assessment of Heavy Metals in Estuaries and the Formation of Pollution Index. Helgoländer Meeresuntersuchungen, 33, 566-575. https://doi.org/10.1007/BF02414780

Varol, M. (2011). Assessment of Heavy Metal Contamination in Sediments of the Tigris River (Turkey) Using Pollution Indices and Multivariate Statistical Techniques. Journal of Hazardous Materials, 195, 355-364. https://doi.org/10.1016/j.jhazmat.2011.08.051

Water Resources Commission (WRC) (2012). National Integrated Water Resources Management (IWRM) Plan. Republic of Ghana, Accra: Water Research Institute. 